Results Operative incised abdominal wall displayed profound allodynia which was reduced by ropivacaine with low dose ketamine combination in the 4 hours following incision. Blood samples these patients showed enhanced levels of 3 cytokines: IL-1 $\beta$, IL- 6 , tumor necrosis factor alpha (TNF $\alpha)$. Ropivacaine with low dose ketamine administration reduced levels. First group lower cytokines levels over second group (mean \pm SD, IL- $1 \beta-4.4 \pm 2.2$ vs. $14.2 \pm 2.4 \mathrm{pg} / \mathrm{mg}$ protein; IL-6- $204.8 \pm 80.0$ vs. $441.2 \pm 90.4 \mathrm{pg} / \mathrm{mg}$ protein; TNF $\alpha-$ $14.4 \pm 4.6$ vs. $58.8 \pm 7.2 \mathrm{pg} / \mathrm{mg})(\mathrm{p}<0.001)$.

Conclusion Ropivacaine with low dose ketamine administration reduces cytokine expression. These studies suggest that Ropivacaine with low dose ketamine combination may alter the inflammatory reaction.

\section{IDENTIFICATION OF NOXIOUS EVENTS FOR NEWBORN INFANTS WITH A NEURAL NETWORK}

doi:10.1136/archdischild-2012-302724.1618

${ }^{1} \mathrm{~N}$ Bressan, ${ }^{1,2} \mathrm{C}$ McGregor, ${ }^{3} \mathrm{M}$ Blount, ${ }^{3} \mathrm{M}$ Ebling, ${ }^{3} \mathrm{D}$ Sow, ${ }^{4,5} \mathrm{~A}$ James. ${ }^{1}$ Business \& Information Technology; ${ }^{2}$ Health Sciences, University of Ontario Institute of Technology, Oshawa, ON, Canada; ${ }^{3}$ BBM TJ Watson Laboratory, Hawthorne, NJ, USA; ${ }^{4}$ Paediatrics, The Hospital for Sick Children; ${ }^{5}$ University of Toronto, Toronto, ON, Canada

Background Recognition of pain experienced by immature and/or critically ill newborn infants in the Neonatal Intensive Care Unit remains a challenge despite the use of objective scoring systems that depend on physiological and behavioural parameters. We consider there is a need to identify pain using only physiological data streams. Methods Data were collected from three preterm male, gestational age $27.25 \pm 0.95$ weeks (mean $\pm S D$ ), birth weight $941.25 \pm 189.31$ grams. Heart rate (HR), mean arterial pressure (MAP), respiratory rate (RR), blood oxygen saturation $\left(\mathrm{SpO}_{2}\right)$ were considered for the NN Input Vector. NN's output were set to ' 1 ' for noxious stimuli pattern (NSP) define as: $\mathrm{HR} \geq 160$ AND MAP $\geq 55$ AND RR $\geq 40$ AND $\mathrm{SpO}_{2}<<90^{1}$. Artifact events were captured in previous study ${ }^{2}$ and integrated with realtime physiological data streams. In this study we correlated the nociceptive event identified by NN with the artifact nociceptive event. Results Events 'vascular access' and 'reintubation' statistically coincide with the NSP defined in 100\%. Event 'routine care' coincides in $52.67 \%$ with NSP. HR $\geq 160$ was evident in $24.6 \%$ of the event occurrence. The events were successfully identified by the NN, shown figure 1.

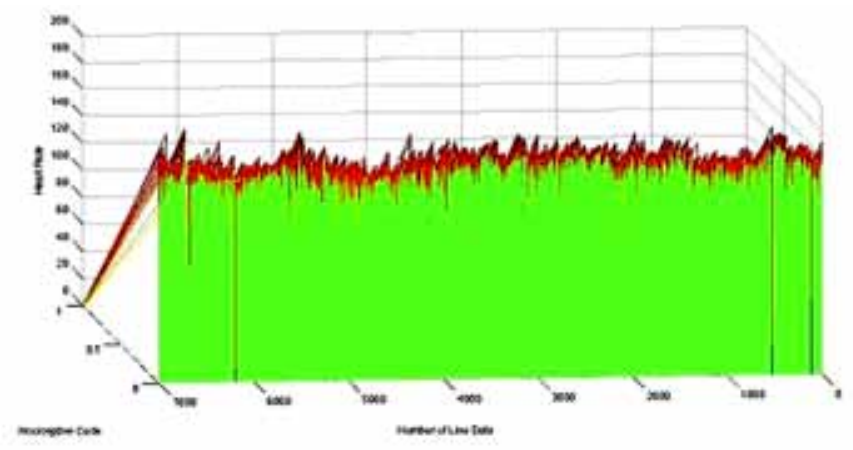

Abstract 1618 Figure 1

Conclusion This study showed correlation of artifact nociceptive event with the physiological data streams NN patterns verifying a positive relation between nociceptive response and non-invasive physiological response. NN developed previously proved to be an accurate tool for deployment in a clinical decision support system.

\section{References}

1. Submitted to ESCTAIC 2012, Romania.

2. 1st ACM International Health Informatics Symposium, 647-655.

\section{PAEDIATRIC PAINFUL SICKLE CELL CRISES: A PROSPECTIVE AUDIT OF ANALGESIC PRACTISE IN A TERTIARY PAEDIATRIC EMERGENCY DEPARTMENT}

doi:10.1136/archdischild-2012-302724.1619

${ }^{1,2,3} \mathrm{MJ}$ Barrett, ${ }^{4} \mathrm{~S}$ McCoy, ${ }^{2,4} \mathrm{~J}$ Cronin, ${ }^{2,4} \mathrm{~A}$ Murphy, ${ }^{5} \mathrm{~A}$ Wakai, ${ }^{6} \mathrm{R}$ Geoghegan, ${ }^{6} \mathrm{C}$ McMahon, ${ }^{4} \mathrm{~S}$ Walsh, ${ }^{2,3,4} \mathrm{R}$ O'Sullivan. 'Paediatric Emergency Research Unit, Department of Emergency Medicine, Our Lady's Children's Hospital Crumlin (OLCHC); ${ }^{2}$ National Children's Research Centre, OLCHC; ${ }^{3}$ Department of Paediatrics, University College Dublin; ${ }^{4}$ Paediatric Emergency Research Unit, Department of Emergency Medicine, Our Lady's Children Hospital, Dublin; ${ }^{5}$ Emergency Care Research Unit, Midlands Regional Hospital, Tullamore; ${ }^{6}$ Department of Haematology, OLCHC, Dublin, Ireland

Introduction Although children with painful sickle cell crises (PSCC) frequently present to the Emergency Department (ED), pain in sickle cell disease is often under-recognised, under-treated and treatment may be delayed. We aimed to evaluate pain assessment and management in children presenting to the ED with PSCC. Methods A 12-month prospective descriptive study of acute pain management of PSCC at an urban tertiary paediatric ED. Pain was assessed by the triage nurse or physician using a validated age appropriate pain scale (Faces, Legs, Activity, Cry, Consolability (FLACC) Scale; Manchester Pain Ruler).

Results There were 96 presentations in 66 patients with PSCC (Table 1). Nineteen $(19.7 \%)$ patients recieved no pre-hospital analgesia.

Abstract 1619 Table 1

\begin{tabular}{|c|c|c|c|}
\hline & $\begin{array}{c}\text { Entire } \\
\text { Cohort }(n=96)\end{array}$ & $\begin{array}{c}\text { Severe pain } \\
\text { Cohort }^{*}(n=56)\end{array}$ & $\begin{array}{c}\text { Moderate } \\
\text { Cohort }^{*}(n=30)\end{array}$ \\
\hline Triage Pain Score & 7/10 (IOR 5-8) & 8/10 (IOR 7-10) & \\
\hline Pain Score at 60 minutes & 5/10 (IOR 2.25-8) & 7/10 (IOR 5-8) & \\
\hline $\begin{array}{l}\text { Cases in line with PED } \\
\text { analgesia guidelines }(\%)\end{array}$ & & $45 \%$ & $95 \%$ \\
\hline $\begin{array}{l}\text { Median time for opioid } \\
\text { 'breakthrough' analgesia }\end{array}$ & & 87 minutes & \\
\hline
\end{tabular}

*severe pain defined as $\geq 7 / 10$ and moderate pain as 3-6 on age-appropriate pain scale

Conclusion PSCC pain is under-treated, under-monitored and adequate treatment of pain is delayed in our ED. Patients with severe pain appear at highest risk for treatment guideline violation. This is predominantly related to lack of opiate administration. An educational intervention, with/without the inclusion of an easily administered, fast-onset and short-acting opiate e.g. intranasal fentanyl, may decrease the time from ED arrival to effective pain relief.

\section{EMERGENCY ANALGESIA ADMINISTRATION IN CHILDREN: RETROSPECTIVE ANALYSIS AND RECOMMENDATIONS}

doi:10.1136/archdischild-2012-302724.1620

${ }^{1} \mathrm{~A}$ Hamdan, ${ }^{2} \mathrm{M}$ Thompson. ${ }^{1}$ Faculty of Medical Sciences, Newcastle University, Newcastle upon Tyne, ${ }^{2}$ Emergency Medicine, Queen Elizabeth Hospital, Gateshead, UK

Introduction Emergency analgesia administration in children is inadequate and guideline is insufficient. We aimed to analyse our department's paediatric pain management to inform and recommend necessary alterations to current practice.

Methods 800 children (0-16 years old) presenting with painful conditions to Queen Elizabeth Hospital Emergency Department within a 40-month period (01/01/2008-28/02/2012) were randomly identified from a prospective audit database and allocated into four groups according to pain scores (no, mild, moderate and severe pain; 200 children in each group). Analgesia types and differential diagnoses were recorded. 